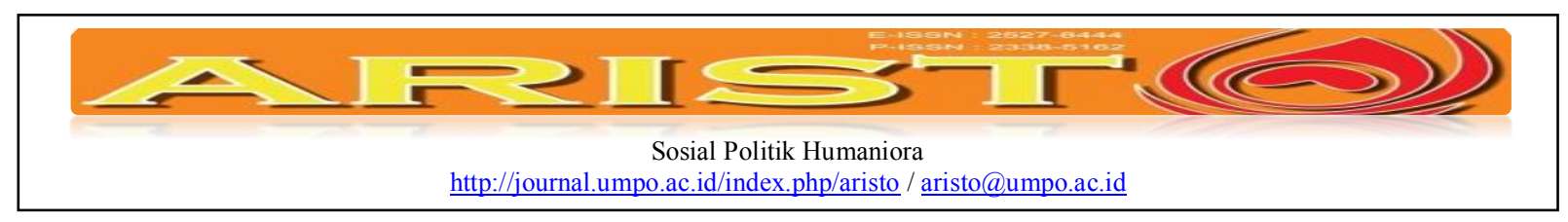

\title{
Analisis Impelementasi Kebijakan Aplikasi Qlue Di Wilayah Jakarta Utara
}

\author{
Restu Rahmawati, Firman \\ Fakultas Ilmu Sosial dan Ilmu Politik \\ Universitas 17 Agustus 1945 Jakarta \\ restu.rahmawati3@gmail.com
}

\begin{abstract}
This writing going to talk about analysis the implementation of application qlue in region North Jakarta. Reason the study is done to see how the implementation of application qlue that is part of the program smart city in jakarta especially in tanjung priok. Research methodology used is the method the qualitative study descriptive to technique data collection of interview. The research results show that the implementation of the application of qlue have not been effective. It was because, the community tanjung priok many cannot discern between qlue application, is that supposed to mean lack of socialization for the public regarding the application of qlue. In addition, obliging heads of the neighborhood report three times a day also is not effective. Of the aspect of the achievement of the policy implications of the (output), application qlue policy it is implemented still not 100 percent, based on the data populi center of the community can only $35.8 \%$ of being contented with the implementation of the application of qlue. This indicates that the target not maximum. Thus, the implementation of application qlue in North Jakarta rudimentary and consequently need to there had been improvements forward to create good governance.
\end{abstract}

Keywords: The implementation of policy, application qlue, e-government.

\begin{abstract}
Abstraksi
Tulisan ini akan membahas tentang analisis implementasi aplikasi qlue diwilayah Jakarta Utara. Alasan penelitian ini dilakukan untuk melihat bagaimana implementasi aplikasi qlue yang merupakan bagian dari program smart city di DKI Jakarta terutama di Kecamatan Tanjung Priok. Metode penelitian yang digunakan adalah metode penelitian kualitatif deskriptif dengan teknik pengumpulan data berupa wawancara. Hasil penelitian menunjukkan bahwa implementasi aplikasi qlue belum efektif. Hal ini dikarenakan, masyarakat Tanjung Priok banyak yang belum mengetahui tentang aplikasi qlue, itu artinya kurang sosialisasi kepada masyarakat terkait aplikasi qlue. Selain itu, mewajibkan ketua RT dan RW melapor tiga kali sehari juga masih belum efektif. Dari aspek pencapaian target kebijakan (output), kebijakan aplikasi qlue implementasinya masih belum 100\%, karena berdasarkan data dari Populi Center masyarakat hanya $35.8 \%$ yang puas dengan implementasi aplikasi qlue. Ini mengindikasikan bahwa pencapaian target belum maksimal. Dengan demikian, implementasi aplikasi qlue di wilayah Jakarta Utara belum sempurna sehingga masih perlu ada perbaikan ke depan untuk menciptakan good governance.
\end{abstract}

Kata Kunci: Implementasi kebijakan, Aplikasi Qlue, E-Government

\begin{tabular}{|ll|}
\hline Submite & $:$ 30 Jan 2017 \\
Review & $:$ 22 April 2017 \\
Accepted & $:$ 30 Mei 2017 \\
Surel Corespondensi & $:$ darwisnasution69@gmail.com \\
\hline
\end{tabular}

Restu Rahmawati, Firman, Analisis Impelementasi Kebijakan Aplikasi Qlue Di Wilayah Jakarta Utara /10/Vol. 05/No. 02 Juni 2017 


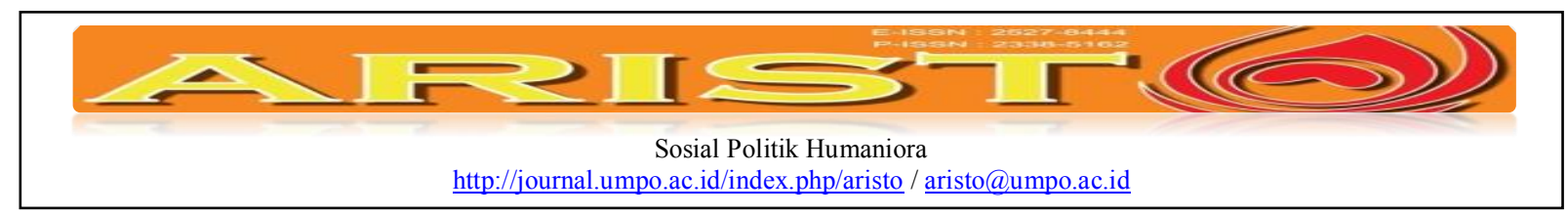

\section{Pendahuluan}

Tulisan ini akan membahas tentang analisis implementasi aplikasi qlue diwilayah Jakarta Utara. Alasan penelitian ini dilakukan mengingat aplikasi qlue ini merupakan bentuk kebijakan yang baru diterapkan oleh Pemprov DKI Jakarta dan pada tahap implementasinya sangat beragam pendapat dari masyarakat dalam menanggapi qlue tersebut. Selain itu alasan penulis mengambil case study di Wilayah Jakarta Utara dikarenakan wilayah Jakarta Utara cenderung mempunyai permasalahan publik yang banyak terutama masalah sampah, jalan yang rusak, dan tingginya tingkat kriminalitas. Atas dasar itu maka kajian ini penting untuk dilakukan, sehingga output penelitian ini dapat berguna sebagai masukan bagi Pemprov DKI Jakarta untuk menciptakan kebijakan yang lebih baik lagi dan tepat sasaran. Barangkali hal semacam ini disebut oleh Ian Patrick Agustin ${ }^{1}$ sebagai sebuah model pragmatisme dalam kebijakan publik yakni sebuah pola yang banyak diadopsi oleh negara-negara berkembang dan disetarakan dengan model kebijakan yang menggunakan rasio untung-rugi dari sebuah kebijakan seperti yang diperkenalkan dalam paradigm cost benefit analysis ${ }^{2}$. Pada praktiknya memang demikian, setiap kebijakan harus mengandung unsur untung-rugi dalam hal nilai kebaikan dan keburukan dari sebuah kebijakan.

Pemerintah Propinsi DKI Jakarta baru saja meluncurkan Qlue, yakni aplikasi yang memungkinkan warga melaporkan keluhannya kepada aparat pemerintah dengan menggandeng CEO qlue yakni Rama Raditya. Aplikasi ini terintegrasi dengan smartcity.jakarta.go.id dan bisa di unduh di android play store. Rencananya, aplikasi ini terintegrasi dengan aplikasi Crop yang diunduh aparat pemerintah. Qlue adalah aplikasi media sosial untuk melaporkan permasalahan kota kepada pemerintah, pihak swasta ataupun saling berbagi informasi sesama warga di lingkungan sekitarmu demi terciptanya smart city. Laporan warga yang masuk melalui aplikasi qlue akan diteruskan kepada pihak terkait dan tetap bisa dipantau perkembangannya di dalam aplikasi qlue maupun di dashboard mycity.qlue.id. akan tetapi, penggunaan aplikasi qlue ini masih ditanggapi secara beragam. Tidak semua ketua RT/RW menyetujui adanya aplikasi qlue.

${ }^{1}$ Nugroho, Riant. Public Policy "Dinamika Kebijakan, Analisis Kebijakan, Manajemen Kebijakan". Jakarta: PT Elex Media Komputindo. Hal 273.

${ }^{2}$ Boardman, Anthony,et.al,2001, cost benefit analysis: Concept and Practices, New York: Prentice Hall. 


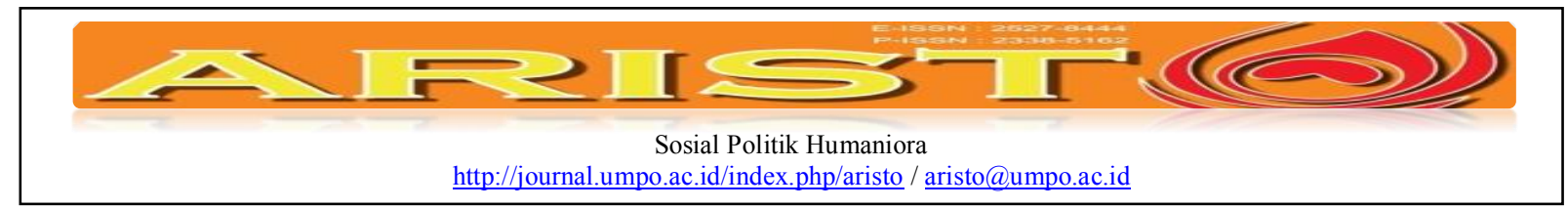

Bagi ketua RT/RW yang belum melek internet maka aplikasi qlue ini hanya menambah beban pekerjaan mereka saja ${ }^{3}$.

Selain itu, Pemprov DKI Jakarta meluncurkan aplikasi qlue guna merespon laporan masyarakat untuk memperbaiki kota Jakarta. Sampah berserakan dan coretan liar dibersihkan dalam hitungan jam berkat laporan masyarakat lewat aplikasi qlue yang terhubung dengan program Jakarta Smart City. Ada lebih 30 pelaporan yang bisa ditujukan bagi pemerintah dan pihak swasta. Dalam sehari laporan warga yang masuk melalui qlue mencapai angka 3.000. Data yang telah diolah dikirimkan kepada pemprov DKI Jakarta tiap bulan sebagai bahan solusi permasalahan kota. ${ }^{4}$ Oleh karena itu, setiap kali laporan masuk pemerintah setempat langsung menindaklanjutinya.

Komitmen Pemerintah Propinsi DKI Jakarta untuk menindaklanjuti setiap laporan tidak main - main, karena kinerja pegawai terlihat jelas lewat layar yang dipantau setiap saat. Dengan demikian, hadirnya aplikasi mobile berbasis media sosial pelaporan, Qlue, di tengah-tengah sibuknya warga Jakarta, kini memberikan ruang yang pasti untuk segera mengadukan permasalahan atau kejadian yang ditemukan penggunanya. Warga yang kerap protes ini dan itu terhadap lingkungan sekitarnya, dapat melaporkan permasalahannya melalui platform digital ini, yang akan diteruskan kepada pihak yang berwenang. Komitmen Pemerintah Propinsi DKI Jakarta untuk menciptakan Jakarta lebih baik lagi melalui qlue, berarti menunjukkan bahwa Pemprov DKI Jakarta telah mengikuti trend aplikasi e-government. E-government digunakan sebagai bentuk inovasi pemerintah daerah dalam memperbaiki pelayanan publik. Hal ini tentunya sejalan dengan apa yang dilakukan oleh negara-negara maju untuk menjamin perbaikan pemerintahan secara keseluruhan.

Aplikasi Qlue ini digagas dan dikembangkan oleh Rama Raditya, yang terinspirasi dari permasalahan Kota Jakarta dan Bulan Desember 2014 diluncurkan. Saat ini Qlue telah memiliki 160 ribu pengguna terdaftar, dengan total persentase keaktifan sebanyak 91\% dan 30-34\% aktif

$3 \quad$ http://m.liputan6.com/tv/read/2499802/video-rama-raditya-aplikasi-qlue-pertama-di-Indonesia\&Ic=idID\&s=1\&m=974\%host=www.google.co.id\&ts=1492405163\&sig=AJsQQ1Cqus3RqrrtZnSbyfR6yUTN6NM3rw. Diakses tanggal 17 April 2017 pukul 13.05 WIB

$4 \quad$ http://m.liputan6.com/tv/read/2499802/video-rama-raditya-aplikasi-qlue-pertama-di-Indonesia\&Ic=idID\&s=1\&m=974\%host=www.google.co.id\&ts=1492405163\&sig=AJsQQ1Cqus3RqrrtZnSbyfR6yUTN6NM3rw. Diakses tanggal 17 April 2017 pukul 13.05 WIB 


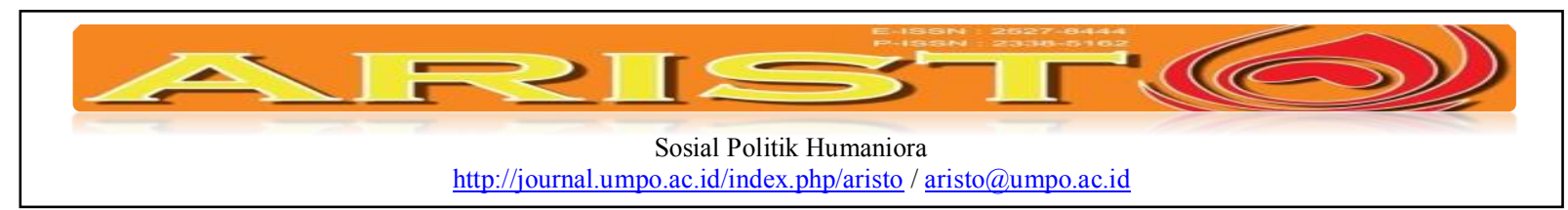

per harinya. Walaupun setiap harinya bertambah jumlah pengguna hingga 1000 pengunduh, namun Rama menilai bahwa angka tersebut hanya mencapai 3\% dari total pengguna ponsel pintar di Jakarta ${ }^{5}$.

Berdasarkan data yang disampaikan di atas, maka kiranya perlu untuk mengkaji persoalan aplikasi qlue ini lebih lanjut. Hal ini dikarenakan, fakta dilapangan menunjukkan masyarakat belum siap dengan adanya aplikasi qlue sehingga keberadaan qlue itu sendiri belum digunakan secara optimal dan pihak Pemerintah Provinsi DKI Jakarta pun masih terus berupaya untuk memformulasikan mengenai bagaimana seharusnya qlue ini digunakan untuk perbaikan Jakarta. Menyoal permasalahan tersebut maka penulis ingin mengkaji tentang implementasi aplikasi qlue di wilayah Jakarta Utara, dengan harapan melalui evaluasi dapat diketahui apakah output benar - benar sampai ke tangan kelompok sasaran kebijakan, atau ada kebocoran, atau penyimpangan dengan merujuk pada model evaluasi yang mencakup efektivitas, efisiensi, kecukupan, equity, responsivitas, dan ketepatan. ${ }^{6}$ Merujuk pada penjelasan diatas, maka penelitian ini akan mengangkat tentang bagaimana analisis implementasi aplikasi qlue di Wilayah Jakarta Utara.

\section{Metode dan Kajian Pustaka}

Penelitian ini menggunakan metode kualitatif dengan analisis deskriptif. Alasan penulis menggunakan metode kualitatif deskriptif, yakni dikarenakan dapat memudahkan penulis memperoleh deskripsi, atau gambaran secara sistematis, faktual dan akurat. Selain itu, penulis menyadari bahwa dengan menggunakan metode kualitatif deskriptif, maka penulis akan mudah memahami sikap, pandangan, perasaan, dan perilaku individu atau kelompok yang telah diteliti. Atau dengan kata lain, analisis deskriptif ini lebih menekankan kepada latar belakang perilaku individu atau kelompok yang diteliti secara keseluruhan. Berdasarkan penjelasan di atas maka observasi dan teknik wawancara mendalam menjadi penting untuk dilakukan.

Selain itu, penelitian ini secara general menggunakan pendekatan Studi Kasus (case study). Alasan peneliti menggunakan pendekatan ini adalah peneliti dapat melakukan penelitian

${ }^{5}$ http://youngsters.id/technopreneur/rama-raditya-ingin-membantu-masalah-perkotaan-dengan-aplikasi-qlue. Diakses tanggal 17 April 2017. Pukul 13.33 wib.

${ }^{6}$ Nugroho, Riant. Public Policy "Dinamika Kebijakan, Analisis Kebijakan, Manajemen Kebijakan". Jakarta: PT Elex Media Komputindo. Hal 497 


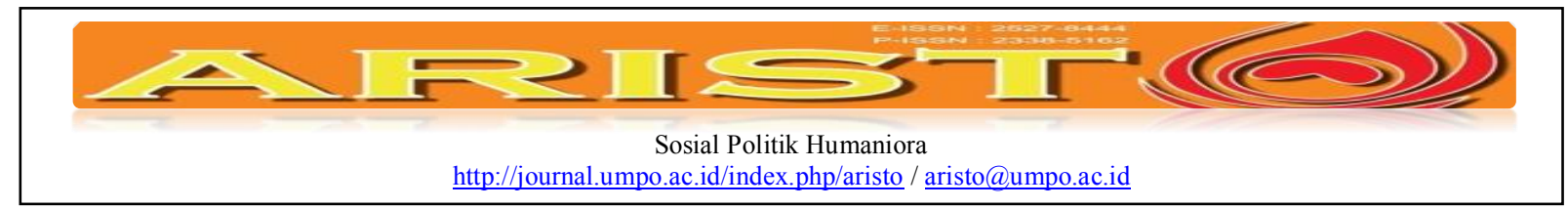

terhadap beberapa atau seluruh aspek potensial dari suatu unit atau serangkaian kasus yang terbatas. Adapun lokasi yang dipilih dalam penelitian ini adalah Wilayah Jakarta Utara yang meliputi Kelurahan Tanjung Priok, Semper, Sunter Agung, dan Cilincing.Informan utama dalam penelitian ini adalah Lurah, ketua RT/RW, operator aplikasi qlue di kelurahan, dan masyarakat Tanjung Priok, Semper, Sunter Agung, dan Cilincing.

Teknik pengumpulan data yang digunakan dalam penelitian ini adalah observasi lapangan, dan wawancara mendalam. Sebelum dilakukan penelitian, peneliti telah melakukan observasi terlebih dahulu yakni dengan melihat aktivitas kepala sekolah, guru, dan para siswa yang mengindikasikan adanya sebuah resistensi. Observasi lapangan ini dilakukan guna mengetahui informasi-informasi, isu-isu aktual nilai-nilai, pola tingkah laku, dan perilaku sosial politik dari para informan penelitian. Setelah itu, kemudian ditentukan informan mana saja yang layak untuk diteliti dengan memperhatikan juga kesediaan mereka untuk bekerjasama dan memberikan data yang akurat.

Teknik kedua yakni wawancara mendalam (indepth interview) dengan informan utama. Pengumpulan data melalui wawancara mendalam ini dilakukan karena peneliti meyakini bahwa melalui wawancara mendalam suatu pandangan, perilaku, dan pola kultural dapat diketahui. Pengumpulan data ini, dilakukan dengan melalui alat perekam. Oleh karena itu, isu-isu penelitian yang terungkap dalam penelitian ini digunakan sebagai data primer. Adapun data sekunder yang dijadikan data pendukung yakni berupa data agregat, buku-buku, majalah, dan jurnal yang terkait dengan masalah politik bahasa dan resistensi masyarakat yang relevan dengan fokus penelitian.

Data dianalisis dengan menggunakan empat tahap yakni pertama, tahap pemilahan (sortiring) data yang terkait dengan resistensi kelompok pendidik. Kedua, tahap klasifikasi (categorizing) dengan melakukan perbandingan antara data yang satu dengan yang lain. Ketiga, tahap komparasi yakni dengan melakukan perbandingan antara data yang satu dengan yang lain. Dan keempat tahap sintesis (synthesizing) dengan melakukan penafsiran terhadap data resistensi dan mengaitkannya dengan kerangka teori sehingga dapat dipahami fenomena resistensi tersebut ${ }^{7}$.

${ }^{7}$ Newman, W. Lawrence. 1997. Social Research Methods: Qualitative and Quantitative Approaches. Allyan \& Bacon, Needham Heights. hal. 427 


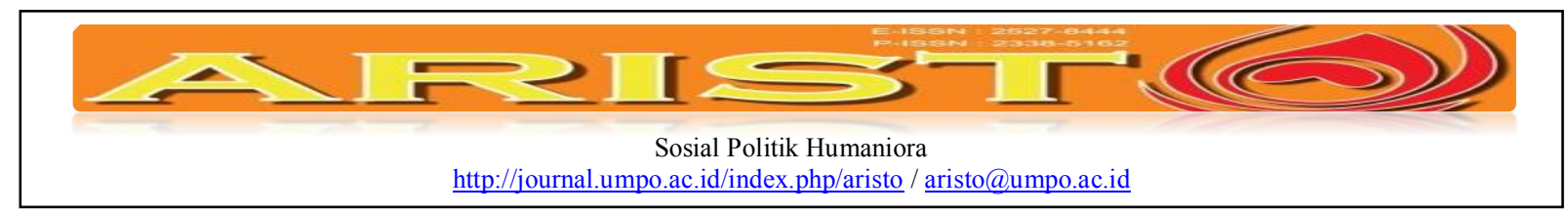

\section{Kebijakan Publik}

Kebijakan publik dalam kepustakaan internasional disebut public policy. Menurut Harold Laswell dan Abraham Kaplan ${ }^{8}$ mendefinisikan kebijakan publik sebagai suatu program yang diproyeksikan dengan tujuan-tujuan tertentu, nilai-nilai tertentu, dan praktik-praktik tertentu (a projected program of goals, values, and practice. Sementara David Easton ${ }^{9}$ mendefinisikan kebijakan publik sebagai akibat aktivitas pemerintah (the impact of government activity). Jadi secara sederhana dapat dikatakan bahwa kebijakan publik adalah:

“.....setiap keputusan yang dibuat oleh Negara, sebagai strategi untuk merealisasikan tujuan dari negara. Kebijakan publik adalah strategi untuk mengantar masyarakat pada masa awal, memasuki masyarakat pada masa transisi, untuk menuju masyarakat yang dicita-citakan". ${ }^{10}$

Berdasarkan penjelasan diatas, maka tujuan kebijakan publik dapat dibedakan dari sisi sumber daya atau resources yakni antara kebijakan publik yang bertujuan men-distribusikan sumber daya negara dan yang bertujuan menyerap sumber daya negara. Berdasarkan hal tersebut, maka tujuan kebijakan publik adalah ${ }^{11}$ :

a) Mendistribusikan sumber daya Negara kepada masyarakat, termasuk alokatif, realokatif, dan redistribusi versus mengabsorpsi atau menyerap sumber daya kedalam Negara.

b) Regulative versus deregulatif.

c) Dinamisasi versus stabilisasi.

d) Memperkuat negara versus memperkuat masyarakat/pasar.

Pada praktiknya, kebijakan publik mengandung multi tujuan yakni untuk menjadikan kebijakan itu sebgai kebijakan yang adil dan seimbang dalam mendorong kemajuan kehidupan bersama. Meskipun pemahaman ini penting, hal yang lebih penting lagi bagi pemerintah atau lembaga publik adalah berkenaan dengan perumusan, implementasi dan evaluasi kebijakan. Pada tahap perumusan masalah maka yang harus dipahami bahwa masalah adalah nilai, kebutuhan,

\section{Hal: 71.}

${ }^{8}$ Laswell, Harold, dan Abraham Kaplan. 1970. Power And Society, New Heaven: YaleUniversity Press.

${ }^{9}$ Easton, David. 1965. A System Analysis of Political Life, New York: Willey. Hal 212.

${ }^{10}$ Nugroho, Riant. Public Policy "Dinamika Kebijakan, Analisis Kebijakan, Manajemen Kebijakan". Jakarta: PT Elex Media Komputindo. Hal: 123.

${ }^{11}$ Ibid hal 140. 


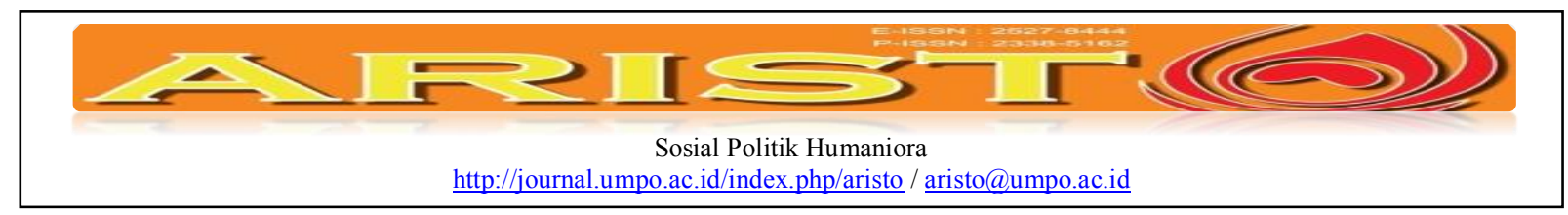

atau kesempatan yang belum terpenuhi yang dapat diidentifikasi untuk kemudian diperbaiki atau dicapai melalui tindakan publik. Fase perumusan masalah terdiri dari proses pencarian masalah, pendefinisian masalah, spesifikasi masalah, dan pengenalan masalah. Lalu berikutnya adalah implementasi kebijakan.

Penelitian ini pada dasarnya adalah untuk mengkaji implementasi kebijakan publik, oleh karena itu penulis akan menjelaskan tentang makna implementasi kebijakan terlebih dahulu. Implementasi kebijakan adalah cara agar sebuah kebijakan dapat mencapai tujuannya. Untuk mengimplementasikan kebijakan publik, ada dua pilihan langkah yang ada, yaitu langsung mengimplementasikan dalam bentuk program atau melalui formulasi kebijakan derivate atau turunan dari kebijakan publik tersebut. Secara umum dapat digambarkan sebagai berikut: ${ }^{12}$

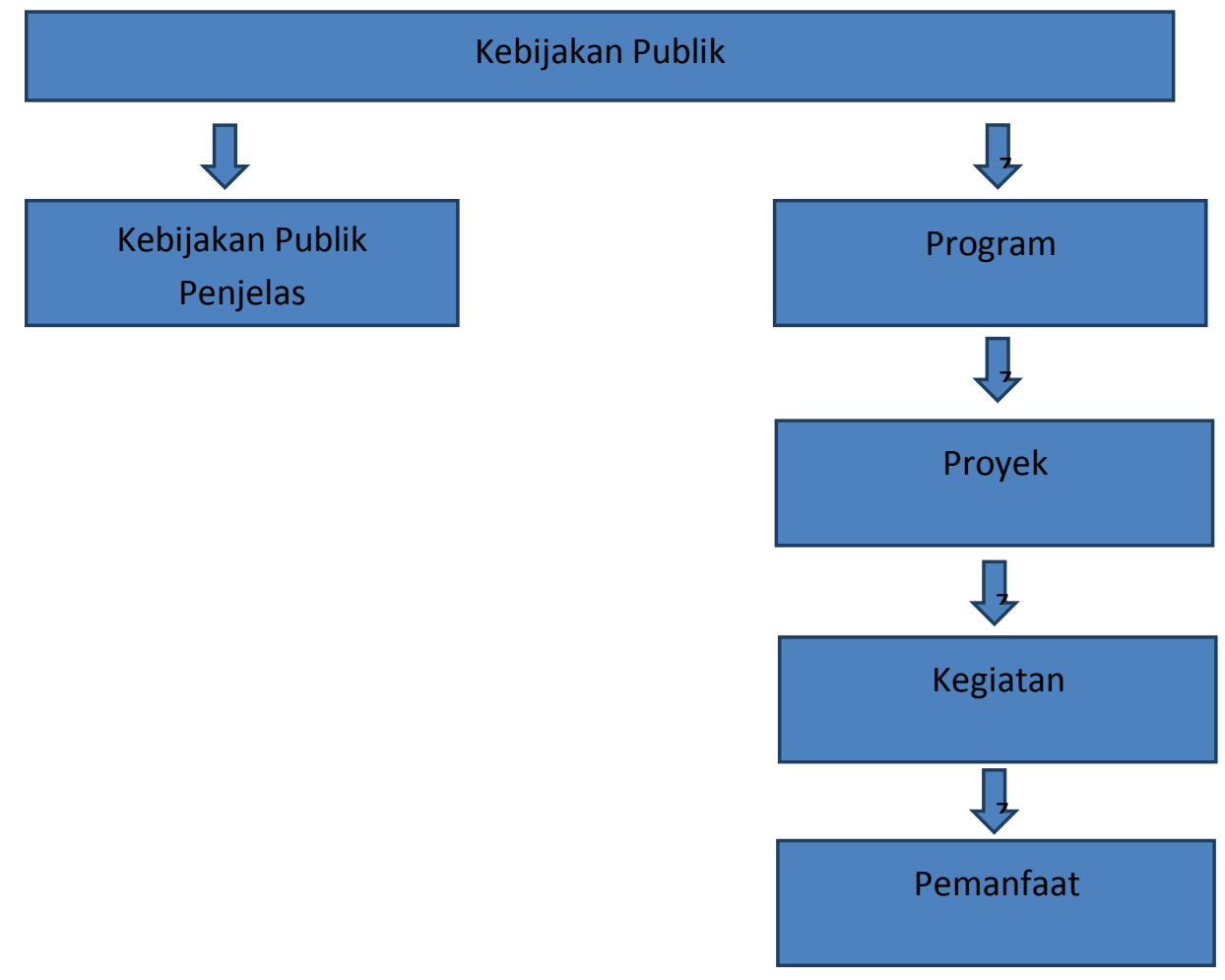

Dalam mengkaji implementasi suatu kebijakan, kiranya penting menggunakan suatu model implementasi kebijakan, guna menganalisis bagaimana implementasi kebijakan aplikasi qlue. Terkait penelitian ini, penulis akan mencoba memaparkan beberapa model implementasi kebijakan seperti model van meter dan van horn yakni model yang menjelaskan bahwa sebuah

\section{${ }^{12}$ Ibid Hal 675}




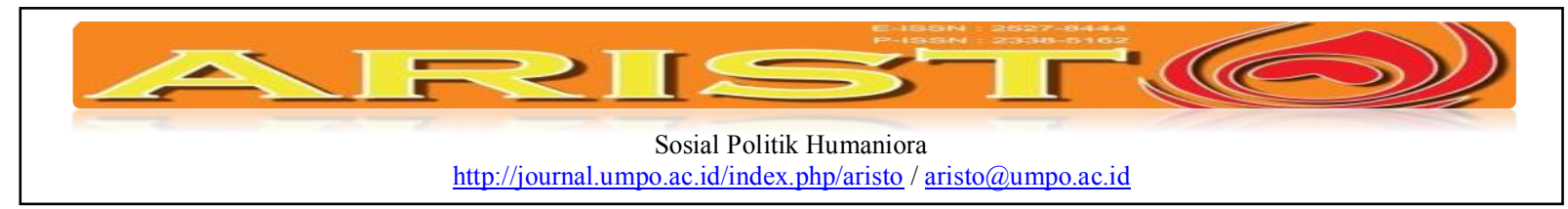

implementasi kebijakan akan dipengaruhi oleh komunikasi antar organisasi, karakteristik agen pelaksana, kondisi ekonomi, sosial, dan politik serta kecenderungan pelaksana. Lalu model berikutnya yakni model mazmanian dan Sabatier yakni suatu model yang melihat bahwa implementasi kebijakan akan dilihat dari beberapa faktor diantaranya ketepatan alokasi sumber dana, keterpaduan hierarkis diantara lembaga pelaksana dan komitmen kualitas kepemimpinan dari pejabat pelaksana. Berikutnya model Hogwood dan Gunn melihat bahwa model ini menjelaskan bahwa yang harus dilihat dari implementasi kebijakan adalah ketersediaan sumber daya yang memadai, termasuk sumber daya waktu, dan perpaduan sumber-sumber yang diperlukan benar-benar ada. Lalu model goggin, Bowman dan Lester menjelaskan bahwa penggerak implementasi kebijakan adalah faktor komunikasi. Terakhir adalah model Grindle yakni indikator implementasi sebuah kebijakan adalah kepentingan yang terpengaruh oleh kebijakan, jenis manfaat yang akan dihasilkan, derajat perubahan yang diinginkan, kedudukan pembuat kebijakan, siapa pelaksana kebijakan, dan sumber daya yang dikerahkan. ${ }^{13}$ Dari beberapa uraian tentang model kebijakan tersebut, maka penulis akan menggunakan model implementasi Grindle untuk mengkaji implementasi kebijakan aplikasi qlue.

Tahap berikutnya dari kebijakan publik tahap evaluasi kebijakan publik. Evaluasi kebijakan memiliki empat fungsi yaitu eksplanasi, kepatuhan, audit, dan akunting. Melalui evaluasi dapat dipotret realitas pelaksanaan program dan generalisasi tentang pola-pola hubungan antar berbagai dimensi realitas yang diamatinya. Dari evaluasi, evaluator dapat mengidentifikasi masalah, kondisi, dan aktor yang mendukung keberhasilan atau kegagalan kebijakan eksplanasi. Melalui evaluasi, dapat diketahui apakah tindakan yang dilakukan para pelaku baik birokrasi maupun pelaku lainnya, sesuai dengan standard dan prosedur yang ditetapkan kebijakan kepatuhan. Melalui evaluasi dapat diketahui apakah output benar-benar sampai ke tangan kelompok sasaran kebijakan, atau ada bocoran, penyimpangan (audit) serta melalui evaluasi dapat diketahui apa akibat ekonomi dari kebijakan tersebut (akunting) ${ }^{14}$.

Dengan demikian, hasil yang dicapai dapat diukur dalam ukuran jangka pendek atau output, dan jangka panjang outcome.

\footnotetext{
${ }^{13}$ Op cit hal 685.

${ }^{14}$ Ibid hal 497.
} 


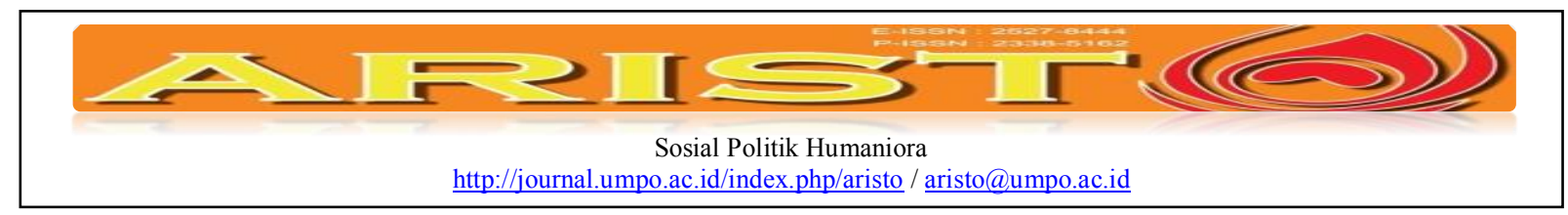

\section{E-Government}

Dalam sebuah masyarakat dan ekonomi yang semakin digerakkan oleh inovasi teknologi, birokrasi di 394egara-negara sedang berkembang harus berhadapan dengan proses tuntutan yang baru yaitu efisiensi, produktivitas, akses rakyat terhadap informasi yang ada dalam birokrasi serta tuntutan kepastian dan rasa aman dan rasa nyaman (convenience). Dalam proses 394egara yang menuju demokrasi selalu terdapat tuntutan dan kepastian dan bahkan kebutuhan akan hakhak "masyarakat yang diperintah" harus diletakkan seiring dengan tujuan-tujuan pembangunan. Secara umum diketahui bahwa diluar lingkungan birokrasi, secara historis, inovasi-inovasi teknologi telah menghasilkan kualitas kehidupan yang meningkat dengan kata lain kalau mau maju ya harus ada inovasi ${ }^{15}$.

Bagi seorang pemimpin pemerintahan yang baik, pelayanan yang baik adalah visi yang ingin selalu diciptakannya dalam menjamin perbaikan pemerintahan secara keseluruhan, dan dalam perkembangannya yang sekarang e-government berhasil menjadi alternative yang umum diterapkan di 394 egara sedang berkembang dalam reformasi pemerintahannya. Dengan demikian, dari sisi akademis aplikasi e-governmentdalam pemerintahan serta hasil yang telah dicapai oleh beberapa Negara maju mengesankan bahwa Negara yang ingin memperbaiki pelayanan publiknya, sedikit atau banyak ia harus berani berinovasi dalam manajemen pelayanan dan peningkatan mutu pelayanan publiknya. Dengan kata lain seolah da adagium: "Tidak ada perbaikan mutu pelayanan 394egara tanpa inovasi. Tidak ada inovasi tanpa aplikasi IT dalam birokrasi. Dengan kata lain tidak ada pelayanan yang baik tanpa e-government". ${ }^{16}$

Merujuk pada penjelasan diatas, maka e-government adalah aplikasi teknologi informasi dan komunikasi dalam dan dengan pihak luar diharapkan meningkatkan performance pemerintahan dan memenuhi ekspektasi masyarakat akan peningkatan kualitas pemerintahan. Selain itu, terbukti bahwa semakin maju suatu 394egara maka semakin tinggi tingkat aplikasi $e$ government. Berikut data yang menunjukkan seberapa jauh suatu negara siap terhadap $e$ government.

15 Said, Mas’ud. 2012. Birokrasi di Negara Birokratis. Makna, Masalah dan Dekonstruksi Birokrasi di Indonesia. Malang: UMM Press. Hal 214.

16 Ibid hal 213. 


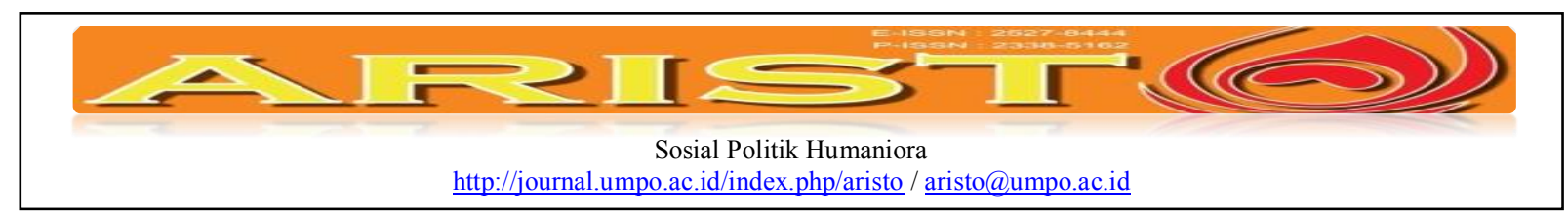

Tabel 2

Peringkat Kesiapan E-Government Secara Global

\begin{tabular}{|l|l|c|}
\hline No. & \multicolumn{1}{|c|}{ Nama Negara } & Indeks Kesiapan Government \\
\hline 1 & Amerika Serikat & 0,927 \\
\hline 2 & Swedia & 0,840 \\
\hline 3 & Australia & 0,831 \\
\hline 4 & Denmark & 0,820 \\
\hline 5 & Inggris & 0,814 \\
\hline 6 & Kanada & 0,806 \\
\hline 7 & Norwegia & 0,778 \\
\hline 8 & Swiss & 0,764 \\
\hline 9 & Jerman & 0,762 \\
\hline 10 & Finlandia & 0,761 \\
\hline 11 & Belanda & 0,746 \\
\hline 12 & Singapura & 0,746 \\
\hline 13 & Republik Korea & 0,737 \\
\hline 14 & Selandia Baru & 0,718 \\
\hline 15 & Islandia & 0,702 \\
\hline 16 & Estonia & 0,697 \\
\hline 17 & Irlandia & 0,697 \\
\hline 18 & Jepang & 0,693 \\
\hline 19 & Perancis & 0,690 \\
\hline 20 & Italia & 0,685 \\
\hline 21 & Austria & 0,676 \\
\hline 22 & Chili & 0,671 \\
\hline 23 & Belgia & 0,670 \\
\hline 24 & Israel & \\
\hline & Unita Natia & \\
\hline
\end{tabular}

Sumber : United Nations, World Public Sector Report, 2003.

Berdasarkan tabel di atas, maka gambaran kesiapan e-government diseluruh dunia adalah terletak pada tingkatan pembangunan ekonomi, sosial dan politik dari negara-negara yang bersangkutan. Sehingga salah satu faktor primer yang turut berperanan dalm menyumbangkan angka kesiapan e-government yang tinggi ialah investasi di masa lalu dalam sumber daya telekomunikasi dan manusia. 


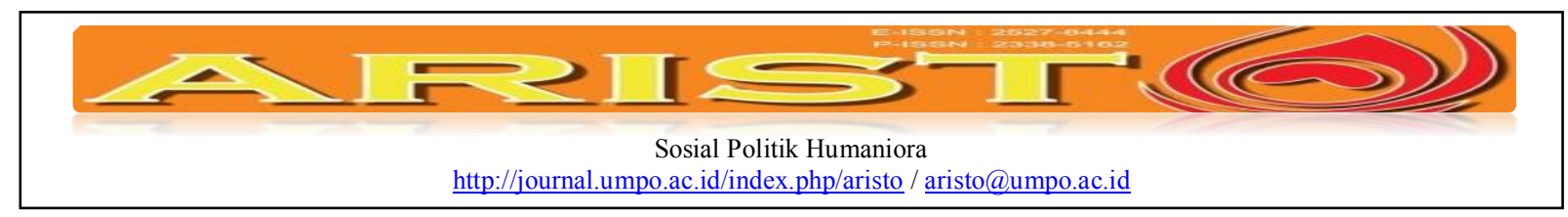

\section{Aplikasi Qlue}

Aplikasi Qlue merupakan sebuah terobosan yang digunakan oleh Pemprov DKI Jakarta sesuai Surat Keputusan (SK) Gubernur Nomor 903 Tahun 2016 tentang mekanisme pelaporan elektronik melalui aplikasi Qlue sebagai wadah bagi warganya untuk melaporkan segala bentuk pengaduan masalah yang ada di DKI Jakarta.Besar kemungkinan aplikasi Qlue ini akan diterapkan secara Nasional.Jika Anda warga DKI Jakarta, Anda bisa ikut berpartisipasi untuk melaporkan segala jenis masalah yang ada, seperti kemacetan, sampah, banjir, pelanggaran, kebakaran, jalan rusak, pengemis, kaki lima liar, kriminal, lampu jalan rusak, pohon tumbang, fasilitas umum, parkir liar, pelanggaran izin bangunan, joki 3 in 1, kawasan bebas rokok.

Qlue adalah aplikasi yang dibuat untuk menjadi jembatan antara warga dan pemerintah yang bertujuan untuk membangun Jakarta agar lebih baik lagi. Dengan aplikasi ini kita bisa bebas untuk menyampaikan keluhan tentang apa yang tidak wajar pada kota Jakarta.

Kita sendiri suka mengeluh tentang jalan yang macet, lampu yang digunakan untuk menerangi jalan sering mati, jalan yang kita lalui sering terjadi pembegalan pada malam hari, atau masalah lainnya yang sering terjadi di Ibukota.

Cara Menggunakan Aplikasi Qlue: 1) Pilih icon plus pada aplikasi Qlue yang letaknya dibawah tengah layar; 2) Akan ada 3 pilihan. Pilih salah satu untuk siapa keluhan akan ditujukan, untuk pemerintah, swasta, atau hanya sekedar untuk berdiskusi.Jika keluhan yang ingin kamu sampaikan itu tidak ada hubungannya dengan pihak perusahaan maka pilih lapor ke pemerintah saja.Lapor ke swasta hanya digunakan jika kejadian atau keluhan yang ingin kamu sampaikan itu bersangkutan dengan sebuah perusahaan.Pilih buat forum untuk mendiskusikan masalah yang mungkin perlu pendapat untuk menyelesaikannya; 3) Ambil foto sebagai bukti tentang keluhan yang ingin kamu sampaikan. 4) Pilih topik yang bersangkutan tentang keluhan yang ingin kamu laporkan; 5) Beri judul dan penjelasan yang lengkap tentang kejadian atau masalah dari keluhan yang ingin kamu laporkan, dan 6) Upload lalu tunggu untuk ditindaklanjuti, jika keluhan kamu benar-benar berkualitas pasti akan segera ditindaklanjuti oleh pemerintah. Warna merah adalah masih menunggu, Warna kuning berarti sedang dalam proses dan Warna hijau tandanya telah selesai menangani keluhan yang kamu laporkan.Berikut contoh dari aplikasi qlue ${ }^{17}$.

\footnotetext{
${ }^{17} \mathrm{http://www.liputan6.com/tag/aplikasi-qlue.} \mathrm{Diakses} \mathrm{tanggal} 6$ Mei 2017
} 

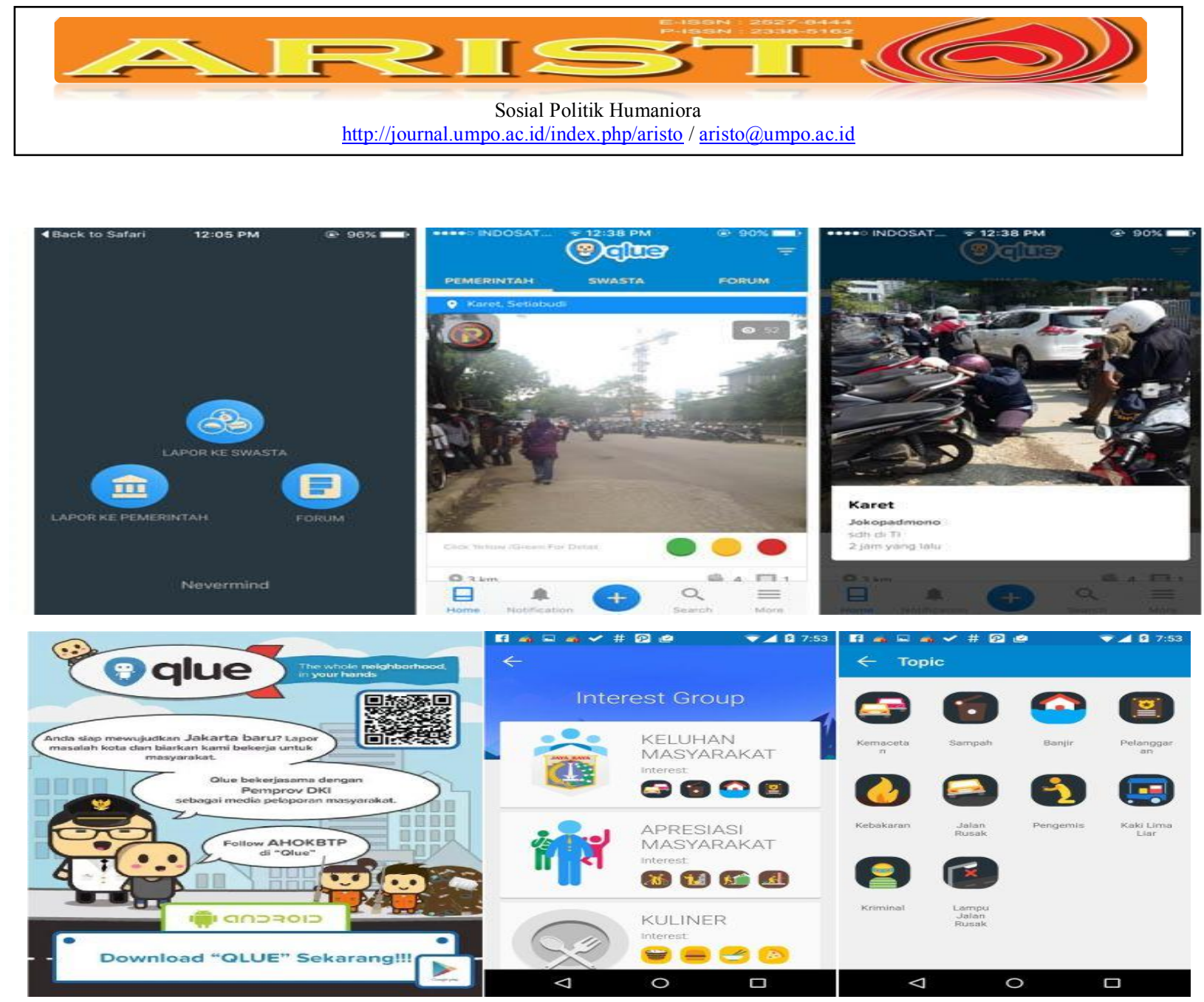

Sumber: https://images.search.yahoo.com/search/images;

\section{Hasil dan Pembahasan}

Berbicara implementasi kebijakan maka berbicara bagaimana suatu kebijakan diterapkan. Terkait penelitian ini maka implementasi kebijakan aplikasi qlue akan berbicara bagaimana pelaksanaan aplikasi qlue ini diterapkan di wilayah Jakarta Utara dengan rentan waktu penelitian sampai bulan Maret 2017. Menyoal implementasi aplikasi qlue di Wilayah Jakarta Utara, maka penulis akan menggunakan model Grindle dalam mengkaji implementasi aplikasi qlue di Wilayah Jakarta Utara. Model Grindle melihat bahwa indikator untuk melihat implementasi sebuah kebijakan adalah kepentingan yang terpengaruh oleh kebijakan, jenis manfaat yang akan dihasilkan, derajat perubahan yang diinginkan, kedudukan pembuat kebijakan, siapa pelaksana kebijakan, dan sumber daya yang dikerahkan.

Berdasarkan data di lapangan dijelaskan bahwa kepentingan yang terpengaruh oleh kebijakan adalah: kepentingan masyarakat yang menginginkan mudah dalam melaporkan keluhan terkait urusan publik kepada pemerintah. Lalu jenis manfaat yang akan diterima 


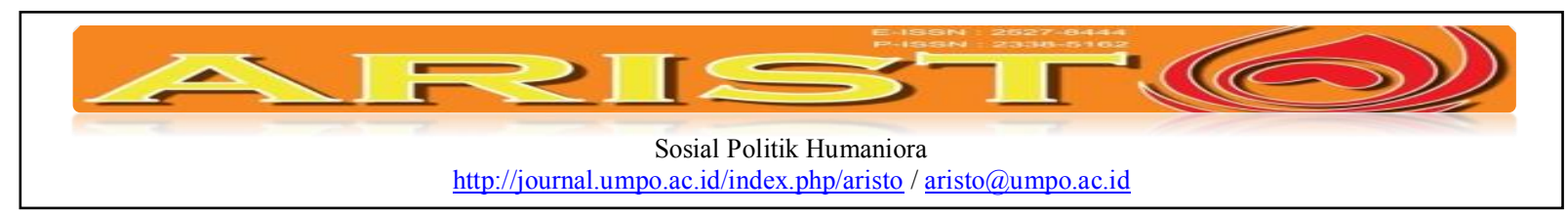

masyarakat dengan adanya aplikasi qlue adalah masyarakat akan mudah untuk melaporkan segala jenis masalah yang ada, seperti kemacetan, sampah, banjir, pelanggaran, kebakaran, jalan rusak, pengemis, kaki lima liar, kriminal, lampu jalan rusak, pohon tumbang, fasilitas umum, parkir liar, pelanggaran izin bangunan, joki 3 in 1, kawasan bebas rokok. Namun berdasarkan data yang didapatkan dari lapangan, implementasi kebijakan aplikasi qlue belum maksimal dikarenakan beberapa persoalan misalnya salah satunya Lukman Rimadi seorang karyawan swasta di kawasan Tanjung Priok. Luqman mengaku berhasil meng-instal aplikasi ini. Hanya, ia gagal melakukan registrasi. Pas install dan memasukkan nama dan umur, qlue nya menjelaskan "name has been used" itu artinya nama yang bersangkutan sudah terdaftar. Tapi pas mencoba login maka ada keterangan "your account is not active" sudah berkali-kali dicoba sampai kapok. Padahal saat peluncuran aplikasi ini ia ingin melaporkan banyak permasalahan dikawasannya. Namun, pada implementasinya aplikasi qlue ini masih ada kendala dalam sistemnya. Ini penting untuk menjadi catatan bagi Gubernur DKI Jakarta dalam menyempurnakan kebijakan qlue.

Lalu, informan berikutnya Abdul Rozak, (28) juga gagal melakukan registrasi. Warga Kelurahan Tanjung Priok ini akan mengadukan terkait kerusakan jalan yang sudah parah menuju akses pelabuhan.Jalan raya Cilincing-Tanjung Priok ini sangat membahayakan pengendara mobil dan motor karena lubang jalan raya sudah parah sehingga rawan terjadi kecelakaan. Terkait dengan persoalan tersebut, sebenarnya sudah ada warga yang melaporkan yakni Abdul Rozak namun karena persoalan sistemnya sehingga informan kesulitan masuk ke dalam aplikasinya maka hal ini menjadi kendala tersendiri bagi sebagian warga Jakarta Utara.

Dari informasi yang didapatkan dari kedua informan tersebut, maka dapat dilihat bahwa ada sebagian warga yang merasa mendapatkan kendala dari system aplikasi qlue itu sendiri yang menyebabkan mereka kesulitan untuk melakukan registrasi dan melaporkan keluhannya. Ini dapat menjadi masukan bagi Pemerintah Propinsi DKI Jakarta supaya berkoordinasi ulang dengan CEO Aplikasi Qlue untuk memperbaiki system aplikasi qlue itu sendiri. Namun, bukan hanya itu saja, warga juga harus terus mengupgrade informasi dan mengikuti sosialisasi terkait aplikasi qlue sehingga kendala yang tadi dihadapi bisa dipecahkan.

Selain kedua informan tersebut, Syafi'i warga Warakas juga menyayangkan lurah dan camat yang tidak tanggap atas pengaduan warga melalui teknonologi canggih ini. Persoalan ini dihadapi Syafi'i karena informan sudah melapor namun tidak ada respon dari lurah dan 


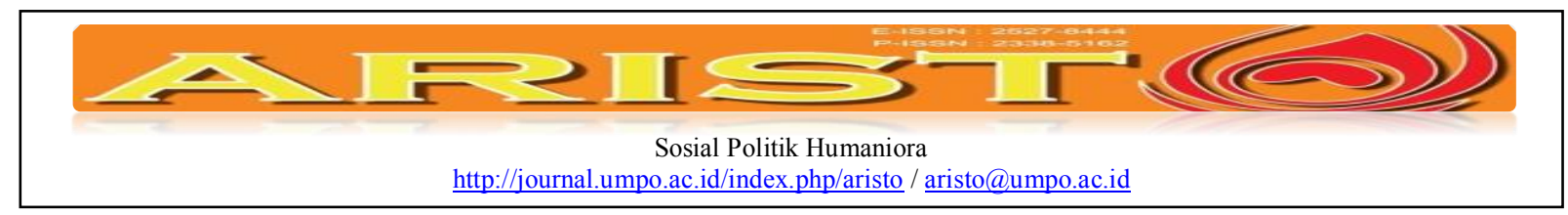

camatnya. Dari kasus tersebut, penulis melihat bahwa lurah kurang tanggap dengan persoalan yang dilaporkan warga, atau lurah tersebut tidak selalu update dengan permasalahan yang ada di dalam qlue setiap harinya sehingga pelaporan warga hanya masuk sampai pada aplikasi qlue saja tanpa ada tindak lanjutnya. Mengapa demikian? Karena dari temuan dilapangan menunjukkan bahwa tidak semua lurah yang pro aktif dengan aplikasi qlue ada juga sebagian dari lurah yang tidak melek teknologi. Inilah kemudian yang menyebabkan kurang tanggapnya lurah atau camat dalam menanggapi pelaporan warga.

Syarifudin ketua RW 5 Kelurahan Kebon Bawang, ia menyoal kewajiban RT/RW melapor sebanyak 3 kali sehari. Keluhannya menjelaskan bahwa hal kewajiban melapor itu tidak efektif karena menurut mereka belum tentu terdapat pelanggaran atau keluhan yang terjadi dalam jangka waktu sehari. Ini tentu saja membebani mereka karena dengan adanya kewajiban tersebut maka seolah-olah mereka dipaksakan untuk menciptakan persoalan setiap harinya untuk dinilai oleh Gubernur. Hal ini mengingat, bahwa RT/RW yang tidak ada laporan maka dianggap tidak bekerja. Semakin banyak laporan maka semakin dianggap bagus kinerjanya. Padahal banyak laporan belum tentu kinerja RT/RW bagus karena banyak juga keluhan warga tidak direspon RT/RW setempat. Inilah kemudian yang menjadi pro kontra adanya aplikasi qlue dikalangan masyarakat Jakarta Utara.

Berdasarkan beberapa penjelasan informan diatas, dapat dilihat bahwa implementasi aplikasi qlue mengundang banyak pendapat dari masyarakat Jakarta khususnya Jakarta Utara. Hal ini sesuai dengan apa yang disampaikan oleh pengamat Kebijakan publik Amir Hamzah ${ }^{18}$ mengatakan bahwa laporan publik digital bernama "qlue" (Jakarta smart city) terkesan menciptakan perang opini antar wilayah, bisa saja karena ulah oknum yang dibayar dalam melakukan pemetaan laporan publik. Misalnya karena kebodohan posting didunia maya masak lurah harus fokus pada jawaban terhadap operator yang tidak tahu wilayah sementara tugas itu tekait SKPD lain yang berwenang. Fakta juga menunjukkan bahwa laporan qlue kini sudah mengarah pada persaingan antar wilayah. Seolah qlue hanya program pengawasan saja bukan bagian dari pelayanan public sevice. Kinerja lurah pun hanya didasarkan pada banyaknya laporan qlue serta penyelesaian permasalahan wilayah. Sementara ada juga wilayah kelurahan yang tidak

18 http://youngsters.id/technopreneur/rama-raditya-ingin-membantu-masalah-perkotaan-dengan-aplikasiqlue. Diakses tanggal 17 April 2017. Pukul 13.33 wib. 


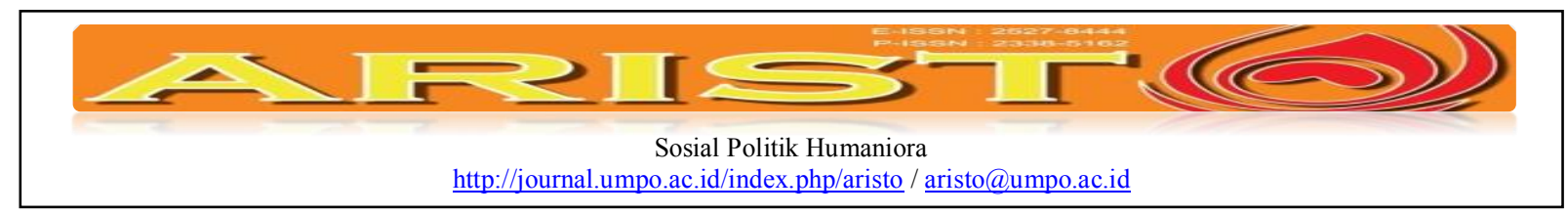

tersentuh oleh laporan qluetapi juga banyak permasalahan yang tidak selesai. Selain itu, aplikasi qlue berbentuk laporan dengan memakai istilah saran, jawaban serta nama samara nampaknya terkondisikan untuk menjadi alat propaganda menjatuhkan istitusi. Beberapa lurah di Jakarta barat dan pusat menyampaikan bahwa posting warna baik merah, kuning dan biru untuk ditindaklanjuti lurah terkadang salah dalam pemetaan oleh yang memposting (pelapor) walaupun lurah sudah menyatakan jawaban qlue sesuai teknis jawaban.

Gubernur Basuki Tjahaja Purnama memberlakukan qlue untuk RT/RW dan memberikan Rp 10.000 untuk sekali pelaporan, namun karena warga banyak yang protes maka pemberlakukan qlue untuk RT dan RW dihapus sehingga pemberlakukan insentif Rp 10.000 pun dihapus dengan alasan RT/RW itu sifatnya pengabdian masyarakat jadi lebih ke ketokohan tidak perlu diberikan insentif cukup uang operasional. Untuk itu, posisi RT/RW dikembalikan kesemula yakni menempati bagian ketokohan masyarakat yang sangat dihargai.

Pada awalnya qlue menjadi tolok ukur kinerja RT/RW. Namun karena sosialisasi dan implementasi yang kurang tepat maka banyak RT dan RW yang mengunggah laporan spam seperti laporan yang diunggah merupakan informasi pribadi seperti KTP warga baru atau surat undangan untuk warga sekitar. Oleh karena itu, dalam beberapa bulan terkahir laporan RT/RW itu tidak lagi ditampilkan secara langsung. Qlue membuat laporan tersebut hanya bisa diakses oleh pihak terkait sehingga tidak membingungkan pengguna lain. Dengan kewajiban untuk melapor tiga kali sehari, kira-kira 90 ribu laporan dari 30 ribu RT/RW di DKI Jakarta. Sementara pengguna Qlue secara keseluruhan ada 700 ribu dan tidak semuanya aktif melapor. Jadi dapat dibayangkan, laporan qlue yang berasal dari RT/RW terbilang cukup besar. Kondisi ini secara tidak langsung juga membingungkan pengguna lain. Sebab qlue sendiri merupakan platform berbagi untuk umum.

Tidak semua masyarakat yang tidak puas dengan adanya aplikasi qlue. Misalnya saja informan berikut yang penulis temui. Endah adalah warga Kelurahan Semper yang menjelaskan bahwa yang bersangkutan sangat terbantu dengan adanya aplikasi qlue. Hal ini dikarenakan, warga jadi bebas untuk melaporkan tanpa harus datang ke kantor kelurahan langsung. Ada beberapa laporannya terkait sampah yang langsung direspon oleh ketua RT/RW. Ini menjadi catatan positif dari warga Semper terkait implementasi aplikasi qlue. 


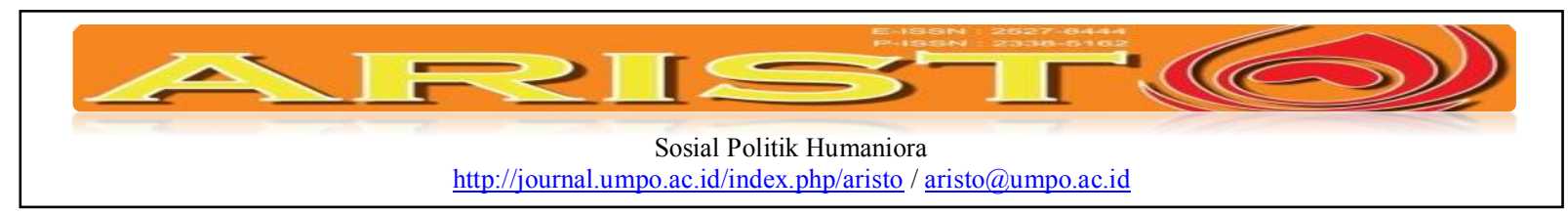

Indikator berikutnya untuk melihat implementasi kebijakan aplikasi qlue adalah derajat perubahan yang diinginkan. Artinya ini berbicara seberapa besar harapan yang ingin dicapai oleh Pemprov DKI Jakarta dengan adanya Aplikasi Qlue tersebut. Harapan yang besar dari Pemprov DKI Jakarta dengan adanya aplikasi qlue ternyata pada tataran implementasinya menurut data Populi Center tingkat kepuasan masyarakat terhadap aplikasi qlue sebesar 35,8 persen $^{19}$. Berdasarkan hal tersebut, maka derajat perubahan yang diinginkan oleh Pemerintah DKI Jakarta sangat besar terhadap masyarakat Jakarta namun kenyataannya tingkat kepuasan masyarakat dengan adanya aplikasi qlue masih rendah.

Lalu indikator kedudukan pembuat kebijakan aplikasi qlue dalam hal ini adalah Gubernur DKI Jakarta Basuki Thajaya Purnama. Dengan kedudukannya sebagai gubernur maka Gubernur DKI Jakarta tersebut mengeluarkan kebijakan e-governance untuk memudahkan masyarakat Jakarta melapor tentang keluhannya. Sedemokratis apapun formulasi kebijakan publik, pada akhirnya yang memutuskan adalah pemimpin ${ }^{20}$ peran pemimpin dalam kebijakan publik teramat vital karena hanya pemimpinlah yang mempunyai tugas pokok memastikan perumusan kebijakan dibuat sesuai dengan seharusnya. Oleh karena itu, begitu pentingnya peran Gubernur DKI Jakarta dalam mengawasi dan menjawab semua permasalahan yang disampaikan warga Jakarta.

Pelaksana kebijakan ini adalah seluruh masyarakat DKI Jakarta. Namun, pada penelitian ini penulis hanya memfokuskan pada masyarakat Jakarta Utara saja. Selaku pelaksana kebijakan tentunya banyak pendapat dari masyarakat DKI Jakarta terhadap implementasi aplikasi qlue tersebut. Sebagaimana yang telah dipaparkan sebelumnya, bahwa ada masyarakat yang pro dan kontra. Masyarakat yang pro sebagian besar merasa diuntungkan dengan adanya kebijakan aplikasi qlue dan kebanyakan mereka adalah orang-orang yang sudah melek teknologi yang paham akan mengoperasionalisasikan aplikasi qlue. Namun, bagi masyarakat yang merasa terbebani dengan adanya aplikasi qlue ini tentu saja kontra dan menganggap ini sulit dijalankan oleh mereka seperti para ketua RT yang merasa terbebani dengan adanya kewajiban wajib lapor. Dengan banyaknya pendapat dari masyarakat terkait aplikasi qlue tersebut, maka ini harus

${ }^{19}$ http://megapolitan.kompas.com/read/2016/06/24/03450051/tingkat.kepuasan.masyarakat.terhadap.pempro v.dki.jakart. Diakses tanggal 18 April 2017. Pukul 09.00 WIB.

${ }^{20}$ Nugroho, Riant. Public Policy "Dinamika Kebijakan, Analisis Kebijakan, Manajemen Kebijakan”. Jakarta: PT Elex Media Komputindo. Hal: 287. 


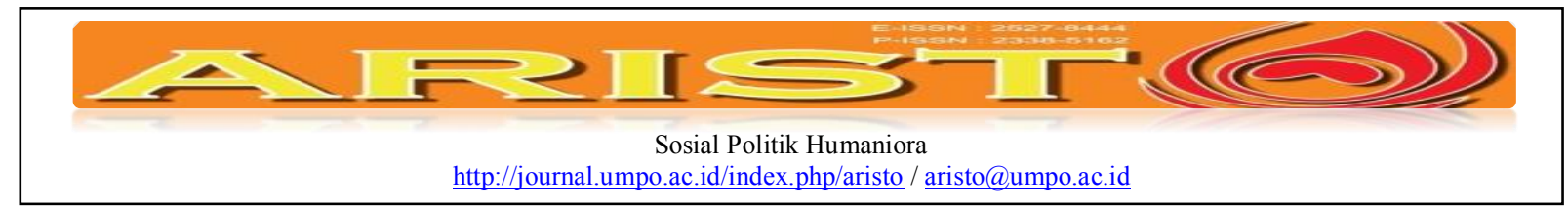

menjadi catatan untuk Pemerintah DKI Jakarta dalam melakukan evaluasi terhadap kebijakan aplikasi qlue. Catatan ini kemudian yang menjadi dasar bagi proses evaluasi kebijakan aplikasi qlue.

Evaluasi kinerja kebijakan publik juga dilakukan dengan melakukan penilaian komprehensif terhadap pencapaian target kebijakan (output), pencapaian tujuan kebijakan (outcome), kesenjangan (gap) antara target dan tujuan dengan pencapaian, pembandingan (benchmarking) dengan kebijakan yang sama di tempat lain yang berhasil, dan identifikasi faktor pendukung keberhasilan dan kegagalan sehingga menyebabkan kesenjangan, dan memberikan rekomendasi untuk menanggulangi kesenjangan. Berdasarkan data mengenai implementasi aplikasi qlue yang dijelaskan diatas, maka evaluasi implementasi aplikasi qlue di Wilayah Jakarta Utara adalah sebagai berikut:

1) Dari aspek pencapaian target kebijakan (output), kebijakan aplikasi qlue implementasinya masih belum 100\%, karena berdasarkan data dari Populi Center masyarakat hanya $35.8 \%$ yang puas dengan implementasi aplikasi qlue. Ini mengindikasikan bahwa pencapaian target belum maksimal. Selain, itu banyaknya keluhan warga Jakarta Utara yang dijelaskan pada bagian sebelumnya mengisyaratkan bahwa aplikasi qlue msih jauh dari target yang diharapkan;

2) Kebijakan aplikasi qlue ini jika dilihat dari pencapaian tujuan kebijakan (outcome) sudah sesuai dengan tujuan kebijakannya yakni untuk tujuan reformasi birokrasi sehingga dapat menciptakan Jakarta lebih baik. Menurut penulis, tujuan adanya aplikasi qlue pada dasarnya baik, namun segala kekurangan yang ada itu persoalan waktu dan proses yang akan menyempurnakan. Sekalipun outputnya juga belum maksimal;

3) Kesenjangan (gap) antara target dan tujuan dengan pencapaian dapat dilihat dengan membandingkan target pencapaian kebijakan dengan pencapaian tingkat kepuasan masyarakat terhadap kebijakan aplikasi qlue tersebut. Jika targetnya adalah 100\% sasaran maka yang puas dimata publik adalah 35.8\% maka masih ada sekitar 64.2\% target yang harus direalisasikan dengan berbagai pembenahan yang ada. Data tersebut menunjukkan bahwa masih ada kesenjangan antara target dan pencapaian dari kebijakan aplikasi qlue. Oleh karena itu, perlu ada upaya pembenahan supaya tujuan kebijakan yakni Kota Jakarta yang tertata dapat terealisasi. 


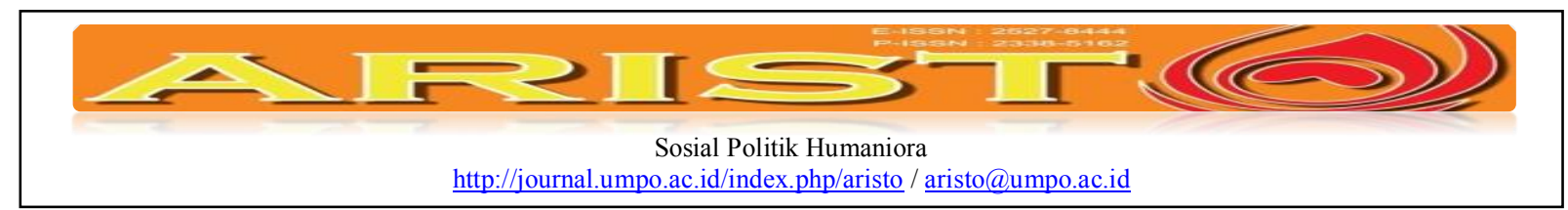

4) Pembandingan (benchmarking) dengan kebijakan yang sama di tempat lain yang berhasil yakni bisa kita lihat dan bandingkan dengan program smart city yang telah berhasil sukses dilakukan di Surabaya. Seharusnya aplikasi qlue ini lebih berhasil di Jakarta karena Jakarta merupakan representasi masyarakat perkotaan yang memiliki akses yang mudah terhadap internet apalagi Jakarta merupakan ibu kota negara. Namun pada implementasinya, masih banyak yang harus diperbaiki.

5) Kebijakan aplikasi qlue ini pada dasarnya adalah sebuah kebijakan yang bagus dan patut untuk didukung oleh masyarakat Jakarta. Mengapa demikian? Karena potensi kebijakan ini akan berhasil sangat tinggi sebab semua perangkat yang mendukung aplikasi qlue terfasilitasi namun perlu dioptimalkan saja. Sedangkan faktor yang mungkin akan menjadi penghambat dari kebijakan tersebut adalah perihal kurangnya sosialisasi, masih adanya ketua RT/RW yang belum melek teknologi, dan rendahnya pengawasan.

\section{Kesimpulan}

Berdasarkan pemaparan diatas, maka kesimpulannya adalah implementasi kebijakan aplikasi qlue apabila dilihat dengan model grindle masih harus terus diperbaiki karena pada tataran implementasinya belum maksimal. Hal ini dikarenakan, sebagian masyarakat Jakarta Utara menganggap bahwa kebijakan aplikasi qlue masih ada kekurangan dalam hal sistemnya yakni susah untuk melakukan registrasi, sosialisasi untuk aplikasi qlue ini masih minim sehingga tidak semua warga yang mengetahui bagaimana cara mengoperasionalisasikan aplikasi qlue sehingga sebagian masyarakat kurang memanfaatkan aplikasi qlue ini dengan baik. Dari sisi RT/RW, dan lurah juga belum melek teknologi secara keseluruhan. Lalu, sebagian lurah juga banyak yang mengeluh terkait wajib lapor 3 kali setiap hari. Berdasarkan implementasi kebijakan aplikasi qlue tersebut, maka rekomendasinya sebagai hasil dari evaluasi kebijakan aplikasi qlue adalah perbaiki sistemnya supaya mudah registrasi, perlu sosialisasi yang intensif harus ke seluruh warga agar layanan ini dapat dimanfaatkan lebih baik, lurah dan camat harus tanggap dan melek gadget, perlu pengawasan yang extra terhadap implementasi aplikasi qlue, harus jelas terkait tujuan dari adanya pelayanan publik yang berbentuk aplikasi qlue supaya kemanfaatannya jelas. 


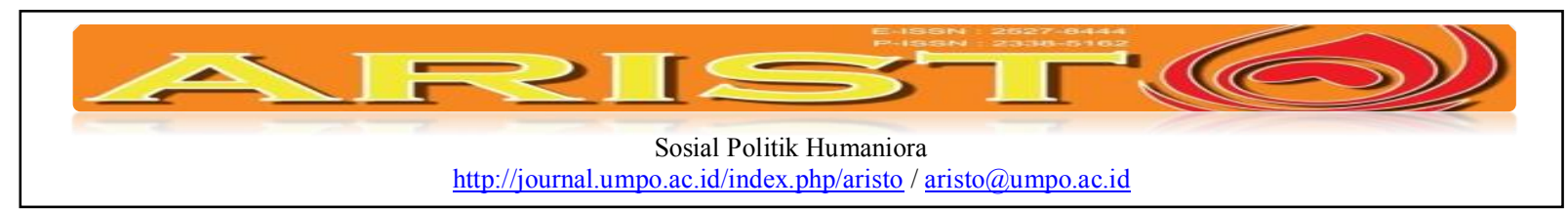

DAFTAR PUSTAKA

B. Mattey Miles and Michael Huberman. 2004. Analisis Data Kualitatif. Universitas Indonesia Press, Jakarta.

Charles O. Jones, An Introduction to the Study of Public Policy. Third Edition, 1984, Monterey: Books/Cole Publishing Company.

Easton, David. 1965. A System Analysis of Political Life, New York: Willey.

Laswell, Harold, dan Abraham Kaplan. 1970. Power And Society, New Heaven: Yale University Press.

Moleong, 2002. Metode Penelitian Kualitatif. PT Rosdakarya, Bandung.

Newman, W. Lawrence. 1997. Social Research Methods: Qualitative and Quantitative Approaches. Allyan \& Bacon, Needham Heights.

Nugroho, Riant. Public Policy "Dinamika Kebijakan, Analisis Kebijakan, Manajemen Kebijakan”. Jakarta: PT Elex Media Komputindo.

Nugroho, Riant. Public Policy "Dinamika Kebijakan, Analisis Kebijakan, Manajemen Kebijakan”. Jakarta: PT Elex Media Komputindo.

Nugroho,Riant. Kebijakan Publik untuk Negara-negara Berkembang”. 2006, Jakarta, Gramedia

Said, Mas'ud. 2012. Birokrasi di Negara Birokratis. Makna, Masalah dan Dekonstruksi Birokrasi di Indonesia. Malang: UMM Press.

Tangkilisan, Hessel Nogi S., 2003, Kebijakan Publik: Untuk Pemimpin Berwawasan Internasional, Yogyakarta: Balairung.

Wahab, Solichin Abdul, 2002. Analisis Kebijaksanaan: Dari Formulasi ke Implementasi Kebijaksanaan Negara, Jakarta: Sinar Grafika

http://youngsters.id/technopreneur/rama-raditya-ingin-membantu-masalah-perkotaan-denganaplikasi-qlue. Diakses tanggal 17 April 2017. Pukul 13.33 wib.

http://m.liputan6.com/tv/read/2499802/video-rama-raditya-aplikasi-qlue-pertama-diIndonesia\&Ic=idID\&s=1\&m=974\%host=www.google.co.id\&ts=1492405163\&sig=AJsQ Q1Cqus3RqrrtZnSbyfR6yUTN6NM3rw. Diakses tanggal 17 April 2017 pukul 13.05 WIB

http://youngsters.id/technopreneur/rama-raditya-ingin-membantu-masalah-perkotaan-denganaplikasi-qlue. Diakses tanggal 17 April 2017. Pukul 13.33 wib 